TITLE:

\title{
iPS cells: A source of cardiac regeneration
}

$\operatorname{AUTHOR}(S)$ :

Yoshida, Yoshinori; Yamanaka, Shinya

CITATION:

Yoshida, Yoshinori ... [et al]. iPS cells: A source of cardiac regeneration. Journal of Molecular and Cellular Cardiology 2011, 50(2): 327-332

ISSUE DATE:

2011-02

URL:

http://hdl.handle.net/2433/139198

RIGHT:

C 2010 Elsevier Ltd; この論文は出版社版でありません。引用の際には 出版社版をご確認ご利用ください。; This is not the published version. Please cite only the published version. 


\title{
iPS cells : A source of cardiac regeneration
}

\author{
Yoshinori Yoshida $^{1,2}, \mathrm{MD}, \mathrm{PhD}$, and Shinya Yamanaka ${ }^{1,2,3,4}, \mathrm{MD}, \mathrm{PhD}$
}

From:

${ }^{1}$ Center for iPS Cell Research and Application, Kyoto University, Kyoto 606-8507, Japan

2 Institute for Integrated Cell-Material Sciences, Kyoto University, Kyoto 606-8507, Japan

${ }^{3}$ Yamanaka iPS Cell Special Project, Japan Science and Technology Agency, Kawaguchi 332-0012, Japan

${ }^{4}$ Gladstone Institute of Cardiovascular Disease, San Francisco, CA 94158, USA

\section{Address for correspondence:}

Yoshinori Yoshida

Center for iPS Cell Research and Application, Institute for Integrated Cell-Material Sciences, Kyoto University,

53 Shogoin-Kawaharacho, Sakyo-ku, Kyoto, 606-8507, Japan

Tel: +81-75-366-7000

Fax: +81-75-366-7023

E-mail: yoshinor@cira.kyoto-u.ac.jp

1. Introduction

A variety of medical and surgical strategies have been developed for the treatment of heart

failure. However, heart failure still remains a major cause of morbidity and mortality in developed countries. Medical interventions for heart failure, which include adjustment of the preload, afterload and sometimes contractility, have limited efficacy in patients. Various types of surgery, including ventricular restoration, ventricular assist device implantation and transplantation, can be applied for only a limited number of patients. Therefore, a new 
strategy to improve the cardiac function and inhibit cardiac remodeling needs to be established. A number of strategies to regenerate heart tissue have been devised to resolve the shortage of available transplantation organs, including the transplantation of cardiomyocytes or cardiomyogenic stem cells.

Several tissue-specific stem and progenitor cells, such as mesenchymal stem cells [1] and endothelial progenitor cells [2], have been reported to possesses the potential to differentiate into cardiomyocytes. In addition, resident cardiac stem cells in the heart have also been reported to be able to differentiate into cardiomyocytes. In 2003, Beltrami et al. reported a population of resident cardiac progenitors with the expression of c-Kit is multipotent, differentiating into cardiomyocytes, smooth cells, and endothelial cells.[3] Cardiac side population cells with the potential for Hoechst dye exclusion and Sca-1+ cells have also been reported to have the potential to express cardiomyocyte-specific genes [4, 5] . Islet-1, a LIM homeodomain transcription factor, is expressed in the progenitor cells of the secondary heart field, and they maintain the ability to differentiate into functional cardiomyocytes both in vivo and in vitro [6]. However, whether these cells are present in the adult human heart remains to be elucidated. While these tissue stem or progenitor cells are an attractive source for stem cell-based cardiac regeneration, their self-renewal potential is limited, and in vitro cardiac differentiation is inefficient. 
Embryonic stem cells (ESCs) and induced pluripotent stem cells (iPSCs) are pluripotent cells that can be propagated indefinitely, and can differentiate into cell types from all three germ layers both in vitro and in vivo. The therapeutic effects of human ESC- and iPSC-derived progeny have been reported in animal models for several diseases [7-11].

2. Establishment of iPS cells

2. 1 Discovery of iPS cells

ESCs are derived from the inner cell mass of mammalian blastocysts, and mouse ESCs were first isolated in 1981 [12, 13]. The human ES cells derived from human blastocysts were first established by James Thomson et al. in 1998 [14].

The iPS cells were first established in 2006 by Takahashi and Yamanaka[15] by the retrovirus-mediated transduction of four transcription factors (c-Myc, Oct3/4, SOX2, and Klf4) into mouse fibroblasts. These reprogrammed cells, which were selected by the expression of a beta-geo cassette (a fusion of the beta-galactosidase and neomycin resistance genes) driven by the mouse Fbx15 promoter, failed to contribute to adult chimeras. To obtain high-quality iPS cells, reprogrammed cells was selected for their expression of either Nanog or Oct3/4 expression, both of which are closely involved in pluripotency. These cells successfully contributed to adult chimeras, while also showing 
germline transmission [16-18].

Human iPS cells were established in 2007 , by the transduction of either the same set of transcription factors (c-Myc, Oct3/4, SOX2, Klf4) or another set of transcription factors (Oct3/4, SOX2, Nanog, Lin28) into human fibroblasts $[19,20]$. These human iPS cells are similar to human ES cells in their morphology, gene expression, and the epigenetic status of pluripotent cell-specific genes, and they can differentiate into the cell types of the three germ layers in vitro and in vivo. Human iPS cells have been reported to be established from skin fibroblasts [19-21], keratinocytes[22], and mobilized CD34+ hematopoietic stem/progenitor cells [23], and differentiated T cells from peripheral blood [24-26]. The human iPS cells provided us with a chance to develop new treatment modalities in the field of regenerative medicine, as well as being useful for in vitro disease modeling for drug screening [27, 28].

2. 2 Advancement of the methods in iPSC generation

iPS cells were initially derived from somatic cells by the retroviral or lentiviral transduction of transcription factors, and transgenes were randomly inserted into the genome of the hosts. There are thus risks associated with the integrated transgenes, such as tumorgenicity. In fact, the chimeras and progenies derived from mouse iPSC have an increased incidence of 
tumor formation primarily due to the reactivation of the c-Myc retrovirus [17]. To avoid these risks, iPS cells without transgenic insertion of c-Myc have been established, even with a low reprogramming efficiency [29]. These Myc - iPS cells achieve germline transmission and, Martinez-Fernandez et al. reported Myc - iPS cells to demonstrate robust cardiac differentiation properties [30, 31]. Recently Nakagawa et al reported that L-Myc, which has little transformation activity, instead of c-Myc, increased the reprogramming efficiency in human cells, and promoted germline transmission, but not tumor formation, in iPSC-derived chimeric mice [32].

Several methods for delivering these transcription factors other than through retroviral or lentiviral transduction have also been devised. iPSCs can now be established by the transduction of the reprogramming factors with adenoviruses, sendaiviruses, plasmid vectors, and removable transposon systems [33-38]. Moreover, mouse and human iPSCs could be established by the direct delivery of recombinant reprogramming proteins $[39,40]$. The repeated administration of synthetic modified messenger RNA has recently been reported to be able to reprogram the human somatic cells into iPS cells with a high efficiency [41]. (Figure 1)

Efforts have been made to improve the reprogramming efficiency and establish iPS cells with either substantially fewer or no genetic alterations. Various growth factors and 
chemical compounds, such as DNA methyltransferase inhibitor (5'-azacytidine and RG108), histone deacetylase inhibitors (e.g. valproic acid), histone methyltransferase inhibitor (BIX-01294), Wnt3A, and ALK5 inhibitor, have recently been found to improve the induction efficiency of iPS cells [42-45]. Hypoxic cultivation or supplementation of vitamin C has also found to increase the efficiency of reprogramming $[46,47]$. The tumor suppressor protein p53 and cell-cycle regulator INK4A have been reported to act as a barrier to reprogramming of somatic cells to iPS cells, and the blockade of these genes also increases the reprogramming efficiency.[48-52] Some transcription factors, such as ESRRB and UTF1, have been found to enhance the reprogramming efficiency [53, 54]. In addition, some microRNAs, including miR-291-3p, miR-294 and miR-295, have also been reported to increase the efficiency of iPSC generation [55].

3. Characterization of pluripotent stem cell clones

As iPS cells have been derived from various tissues, it is unclear whether these cells derived from various tissues have the same characteristics as pluripotent stem cells.

To characterize ES/iPS cell lines, an expression analysis using RT-PCR for mRNA and immunocytochemistry for proteins can be used. Embryoid body formation can be 
applied to assess the in vitro differentiation of iPS cells. Directed differentiation into specific cell types, such as neurons, can be performed to assess the differentiation capacity of iPS cell lines. Miura et al. reported that mouse iPS cells established from fetal and adult fibroblasts vary in the frequency of refractory cells, which remain undifferentiated after undergoing neuronal differentiation [56] .

The most stringent criterion for mouse ES/iPS cells is their ability to generate germline-competent adult mouse chimeras, and thus undergo germline transmission. Mouse iPS cells generated with OSK and Tbx3, a transcription factor related to the maintenance of pluripotency, have recently been reported to improve the germ-cell contribution to the gonads and germline transmission frequency [57].

These in vitro and in vivo data clearly show that there are intrinsic qualitative differences between iPS cell lines and that the strict characterization of iPS cell lines is necessary.

Mouse ES cells are derived from the inner cell mass of blastocysts, and another type of pluripotent stem cells (epiblast stem cells) have recently been reported to have been generated [58, 59]. The mouse ES cells and epiblast stem cells differ in their morphology, responses to signaling pathways that support self-renewal, and epigenetic status. Mouse ES cells require LIF/STAT signaling for self-renewal and WNT/ $\beta$-catenin signaling supports 
the maintenance of pluripotency in ES cells. The FGF/ERK pathway promotes the differentiation of mouse ES cells. Mouse ES cells have been reported to be maintained by adding a GSK3 $\beta$ inhibitor which promotes WNT/ $\beta$-catenin signaling and a MEK inhibitor to block the FGF/ERK pathway [60].

Human ES cells share several features with mouse epiblast stem cells and thus are different from mouse ES cells. Human ES cells do not respond to LIF, and FGF/ERK signal promotes self-renewal. In lines of human ES cells derived from females, inactivation of the $X$ chromosome is observed (XaXi) [61]. Hanna et al. reported the ectopic induction of Oct4, KIf4, and KIf2, combined with LIF, GSK3 $\beta$ inhibitor, and MEK inhibitor, to make it possible to convert the ES cells into a more immature state with an active X-chromosome (XaXa) [62]. These converted human ES cells have growth properties, gene expression profiles, and a signaling pathway-dependence similar to mouse ES cells. It was also reported that human ES cells with two active $X$ chromosomes $(\mathrm{XaXa})$ could be generated under hypoxic conditions (5\% oxygen) [63].

As noted above, there are variations in the characteristics of ES/ iPS cell lines, and the optimal method to best establish and maintain appropriate ES/iPS cell lines for ES/iPS cell technology applications still remains to be elucidated. Further studies are therefore required. 
Although the demonstration of germline-competent chimera formation and teratoma

formation is very important to evaluate the pluripotency of stem cells, whether or not it should be applied for evaluating all iPS cells is controversial $[64,65]$. For the purposes of either regenerative medicine or disease modeling, the optimal source cells do not have to be germline-competent or teratoma-competent, as long as they have the ability of self-renewal and differentiation into the necessary target cells [66].

4. Generation of cardiomyocytes from pluripotent stem cells

Mouse and human ES/iPS cells can differentiate into various cell types, including cardiomyocytes, neuronal cells, and embryonic erythrocytes [67-70]. However, the efficiency of cardiomyocyte differentiation is poor and the differentiated cells are a heterogeneous mixture of various types of cells. To improve the efficiency of cardiomyocyte differentiation, the directed differentiation of ES/iPS cells into cardiomyocytes was induced by the supplementation of signaling molecules, such as Activin A and BMP4 $[8,10]$.

It has so far been reported that human cardiomyocytes could be induced from pluripotent stem cells by several methods (Figure 2). Using an embryoid body formation assay, human ES/iPS cells can differentiate into beating cardiomyocytes in the presence of fetal bovine 
serum [71-73], Under the serum-free conditions, with the supplementation of several cytokines, including Activin A and BMP4, the embryoid body can efficiently differentiate into cardiomyocytes [10]. Coculture with END-2 cells, visceral endoderm-like cells, also induce the cardiomyocytes from undifferentiated human ES cells $[74,75]$. In a monolayer culture system of human ES/iPS cells, the directed differentiation of hES cells into cardiomyocytes can be achieved by sequential treatment with activin A and BMP4 [8].

The identification and isolation of a cardiac precursor cell population is expected to provide a source of cells for tissue regeneration, while also providing valuable insight into cardiac development. Several recent studies focused on identifying these progenitor cells. These studies have reported that cardiac cells including cardiomyocytes, endothelial cells, and smooth muscle cells, may arise from cardiovascular progenitor populations with the expression of specific markers, such as Flk-1, c-kit, and Isl-1.[10, 76-80] Recently, Yang et al. reported a population of cardiovascular progenitor cells with low KDR and no c-Kit expression to be able to efficiently differentiate into cardiomyocytes in an in vitro differentiation system using human ES cells [10].

A high-throughput screening system has also been utilized to identify small molecules that simulate the generation of cardiomyocytes from pluripotent stem cells. Using the high-throughput screening system, ascorbic acid was found to enhance the 
differentiation of ES cells into cardiomyocytes [81].

Insight into the development of the heart can be further acquired through the observation of differentiation of ES cells into cardiomyocytes. Several studies have therefore focused on the development of cardiac tissue during mouse ES cell differentiation in vitro.[67, 82]. Developmental studies of human cardiomyocytes are now possible as a result of the recent availability of human ES/iPS cells. Moreover, ES/iPS cell-derived cardiomyocytes can also be used for the study of disease-specific cells, screening for new drugs, as well as for clinical application as a novel cell therapy.

5. Transplantation of cardiomyocytes derived from ES/ iPS cells

Human myocardium has recently been reported to form in infarcted rodent hearts using human ES cell-derived cardiomyocytes $[8,83,84]$. Nelson et al. reported that the intramyocardial delivery of mouse iPS cells also achieved the in situ regeneration of cardiac tissue, while also improving the post-ischemic cardiac function [85]. The poor survival of transplanted cells hinders the effective grafting of the working myocardium. The formation of an aggregation of derived cardiomyocytes or layered cell sheets of the cultured cardiomyocytes has been reported to improve the survival of grafted cardiac cells $[86,87]$. 
As other types of transplanted cells, such as myoblasts or mononuclear bone marrow cells

can be delivered by surgical procedures (epicardial approach) or cardiac catheter procedures (endocardial or intracoronary approach) [88, 89], these delivery methods will be able to be applied to the transplantation of iPS cell-derived cardiac cells. However, several safety issues including teratoma formation still need to be addressed, before these technologies can be successfully used in clinical applications.

\section{Acknowledgements}

We are grateful to Rie Kato, Eri Nishikawa, Sayaka Takeshima, Yuko Otsu, and Haruka Hasaba for their valuable administrative support.

\section{Sources of Funding}

This study was supported in part by Grants-in-Aid for Scientific Research of JSPS and MEXT (to S.Y. and Y. Y.), a grant from the Leading Project of MEXT, and a grant from the Program for Promotion of Fundamental Studies in Health Sciences of NIBIO.

\section{Disclosures}

None. 


\section{References}

[1] Makino S, Fukuda K, Miyoshi S, Konishi F, Kodama H, Pan J, et al. Cardiomyocytes can be generated from marrow stromal cells in vitro. J Clin Invest. 1999 Mar; 103(5): 697-705.

[2] Badorff C, Brandes RP, Popp R, Rupp S, Urbich C, Aicher A, et al. Transdifferentiation of blood-derived human adult endothelial progenitor cells into functionally active cardiomyocytes. Circulation. 2003 Feb 25; 107(7): 1024-32.

[3] Beltrami AP, Barlucchi L, Torella D, Baker M, Limana F, Chimenti S, et al. Adult cardiac stem cells are multipotent and support myocardial regeneration. Cell. 2003 Sep 19; 114(6): 763-76.

[4] Pfister O, Mouquet F, Jain M, Summer R, Helmes M, Fine A, et al. CD31- but Not CD31+ cardiac side population cells exhibit functional cardiomyogenic differentiation. Circ Res. 2005 Jul 8; 97(1): 52-61.

[5] Oh H, Bradfute SB, Gallardo TD, Nakamura T, Gaussin V, Mishina Y, et al. Cardiac progenitor cells from adult myocardium: homing, differentiation, and fusion after infarction. Proc Natl Acad Sci U S A. 2003 Oct 14; 100(21): 12313-8.

[6] Laugwitz KL, Moretti A, Lam J, Gruber P, Chen Y, Woodard S, et al. Postnatal isl1+ cardioblasts enter fully differentiated cardiomyocyte lineages. Nature. 2005 Feb 10; 433(7026): 647-53.

[7] Keirstead HS, Nistor G, Bernal G, Totoiu M, Cloutier F, Sharp K, et al. Human embryonic stem cell-derived oligodendrocyte progenitor cell transplants remyelinate and restore locomotion after spinal cord injury. J Neurosci. 2005 May 11; 25(19): 4694-705.

[8] Laflamme MA, Chen KY, Naumova AV, Muskheli V, Fugate JA, Dupras SK, et al. Cardiomyocytes derived from human embryonic stem cells in pro-survival factors enhance function of infarcted rat hearts. Nat Biotechnol. 2007 Sep; 25(9): 1015-24.

[9] Yang D, Zhang ZJ, Oldenburg M, Ayala M, Zhang SC. Human embryonic stem cell-derived dopaminergic neurons reverse functional deficit in parkinsonian rats. Stem Cells. 2008; 26: 55-63.

[10] Yang L, Soonpaa MH, Adler ED, Roepke TK, Kattman SJ, Kennedy M, et al. Human cardiovascular progenitor cells develop from a KDR+ embryonic-stem-cell-derived population. Nature. 2008 May 22; 453(7194): 524-8.

[11] Lamba DA, Gust J, Reh TA. Transplantation of human embryonic stem cell-derived photoreceptors restores some visual function in Crx-deficient mice. Cell Stem Cell. 2009 Jan 
9; 4(1): 73-9.

[12] Evans MJ, Kaufman MH. Establishment in culture of pluripotential cells from mouse embryos. Nature. 1981; 292(5819): 154-6.

[13] Martin GR. Isolation of a pluripotent cell line from early mouse embryos cultured in medium conditioned by teratocarcinoma stem cells. Proc Natl Acad Sci U S A. 1981; 78(12): 7634-8.

[14] Thomson JA, Itskovitz-Eldor J, Shapiro SS, Waknitz MA, Swiergiel JJ, Marshall VS, et al. Embryonic stem cell lines derived from human blastocysts. Science. 1998 Nov 6; 282(5391): 1145-7.

[15] Takahashi K, Yamanaka S. Induction of pluripotent stem cells from mouse embryonic and adult fibroblast cultures by defined factors. Cell. 2006 Aug 25; 126(4): 663-76. [16] Maherali N, Sridharan R, Xie W, Utikal J, Eminli S, Arnold K, et al. Directly reprogrammed fibroblasts show global epigenetic remodeling and widespread tissue contribution. Cell Stem Cell. 2007 Jun 7; 1(1): 55-70.

[17] Okita K, Ichisaka T, Yamanaka S. Generation of germline-competent induced pluripotent stem cells. Nature. 2007 Jul 19; 448(7151): 313-7.

[18] Wernig M, Meissner A, Foreman R, Brambrink T, Ku M, Hochedlinger K, et al. In vitro reprogramming of fibroblasts into a pluripotent ES-cell-like state. Nature. $2007 \mathrm{Jul}$ 19; 448(7151): 318-24.

[19] Takahashi K, Tanabe K, Ohnuki M, Narita M, Ichisaka T, Tomoda K, et al. Induction of pluripotent stem cells from adult human fibroblasts by defined factors. Cell. 2007 Nov 30; 131(5): 861-72.

[20] Yu J, Vodyanik MA, Smuga-Otto K, Antosiewicz-Bourget J, Frane JL, Tian S, et al. Induced pluripotent stem cell lines derived from human somatic cells. Science. 2007 Dec 21; 318(5858): 1917-20.

[21] Park IH, Zhao R, West JA, Yabuuchi A, Huo H, Ince TA, et al. Reprogramming of human somatic cells to pluripotency with defined factors. Nature. 2008 Jan 10; 451(7175): 141-6.

[22] Aasen T, Raya A, Barrero MJ, Garreta E, Consiglio A, Gonzalez F, et al. Efficient and rapid generation of induced pluripotent stem cells from human keratinocytes. Nat Biotechnol. 2008 Nov; 26(11): 1276-84.

[23] Loh YH, Agarwal S, Park IH, Urbach A, Huo H, Heffner GC, et al. Generation of induced pluripotent stem cells from human blood. Blood. 2009 May 28; 113(22): 5476-9.

[24] Loh YH, Hartung O, Li H, Guo C, Sahalie JM, Manos PD, et al. Reprogramming of T cells from human peripheral blood. Cell Stem Cell. 2010 Jul 2; 7(1): 15-9.

[25] Seki T, Yuasa S, Oda M, Egashira T, Yae K, Kusumoto D, et al. Generation of 
induced pluripotent stem cells from human terminally differentiated circulating T cells. Cell Stem Cell. 2010 Jul 2; 7(1): 11-4.

[26] Staerk J, Dawlaty MM, Gao Q, Maetzel D, Hanna J, Sommer CA, et al. Reprogramming of human peripheral blood cells to induced pluripotent stem cells. Cell Stem Cell. 2010 Jul 2; 7(1): 20-4.

[27] Yoshida Y, Yamanaka S. Recent stem cell advances: induced pluripotent stem cells for disease modeling and stem cell-based regeneration. Circulation. 2010 Jul 6; 122(1): 80-7. [28] Yamanaka S. Patient-specific pluripotent stem cells become even more accessible. Cell Stem Cell. 2010 Jul 2; 7(1): 1-2.

[29] Nakagawa M, Koyanagi M, Tanabe K, Takahashi K, Ichisaka T, Aoi T, et al. Generation of induced pluripotent stem cells without Myc from mouse and human fibroblasts. Nat Biotechnol. 2008 Jan; 26(1): 101-6.

[30] Martinez-Fernandez A, Nelson TJ, Yamada S, Reyes S, Alekseev AE, Perez-Terzic $\mathrm{C}$, et al. iPS programmed without c-MYC yield proficient cardiogenesis for functional heart chimerism. Circ Res. 2009 Sep 25; 105(7): 648-56.

[31] Martinez-Fernandez A, Nelson TJ, Ikeda Y, Terzic A. c-MYC independent nuclear reprogramming favors cardiogenic potential of induced pluripotent stem cells. J Cardiovasc Transl Res. 2010 Feb; 3(1): 13-23.

[32] Nakagawa M, Takizawa N, Narita M, Ichisaka T, Yamanaka S. Promotion of direct reprogramming by transformation-deficient Myc. Proc Natl Acad Sci U S A. 2010 Aug 10; 107(32): 14152-7.

[33] Stadtfeld M, Nagaya M, Utikal J, Weir G, Hochedlinger K. Induced Pluripotent Stem Cells Generated Without Viral Integration. Science. 2008 Sep 25; 322(5903): 945-9.

[34] Okita K, Nakagawa M, Hyenjong H, Ichisaka T, Yamanaka S. Generation of Mouse Induced Pluripotent Stem Cells Without Viral Vectors. Science. 2008 Oct 9; 322(5903): 949-53.

[35] Kaji K, Norrby K, Paca A, Mileikovsky M, Mohseni P, Woltjen K. Virus-free induction of pluripotency and subsequent excision of reprogramming factors. Nature. 2009 Apr 9; 458(7239): 771-5.

[36] Woltjen K, Michael IP, Mohseni P, Desai R, Mileikovsky M, Hamalainen R, et al. piggyBac transposition reprograms fibroblasts to induced pluripotent stem cells. Nature. 2009 Apr 9; 458(7239): 766-70.

[37] Yusa K, Rad R, Takeda J, Bradley A. Generation of transgene-free induced pluripotent mouse stem cells by the piggyBac transposon. Nat Methods. 2009 May; 6(5): 363-9.

[38] Fusaki N, Ban H, Nishiyama A, Saeki K, Hasegawa M. Efficient induction of 
transgene-free human pluripotent stem cells using a vector based on Sendai virus, an RNA virus that does not integrate into the host genome. Proc Jpn Acad Ser B Phys Biol Sci. 2009; 85(8): 348-62.

[39] Zhou H, Wu S, Joo JY, Zhu S, Han DW, Lin T, et al. Generation of induced pluripotent stem cells using recombinant proteins. Cell Stem Cell. 2009 May 8; 4(5): 381-4.

[40] Kim D, Kim CH, Moon JI, Chung YG, Chang MY, Han BS, et al. Generation of human induced pluripotent stem cells by direct delivery of reprogramming proteins. Cell Stem Cell. 2009 Jun 5; 4(6): 472-6.

[41] Warren L, Manos PD, Ahfeldt T, Loh YH, Li H, Lau F, et al. Highly Efficient Reprogramming to Pluripotency and Directed Differentiation of Human Cells with Synthetic Modified mRNA. Cell Stem Cell. 2010 Sep 29.

[42] Huangfu D, Maehr R, Guo W, Eijkelenboom A, Snitow M, Chen AE, et al. Induction of pluripotent stem cells by defined factors is greatly improved by small-molecule compounds. Nat Biotechnol. 2008 Jul; 26(7): 795-7.

[43] Huangfu D, Osafune K, Maehr R, Guo W, Eijkelenboom A, Chen S, et al. Induction of pluripotent stem cells from primary human fibroblasts with only Oct4 and Sox2. Nat Biotechnol. 2008 Oct 12; 26(11): 1269-75.

[44] Shi Y, Do JT, Desponts C, Hahm HS, Scholer HR, Ding S. A combined chemical and genetic approach for the generation of induced pluripotent stem cells. Cell Stem Cell. 2008 Jun 5; 2(6): 525-8.

[45] Maherali N, Hochedlinger K. Tgfbeta signal inhibition cooperates in the induction of iPSCs and replaces Sox2 and cMyc. Curr Biol. 2009 Nov 3; 19(20): 1718-23.

[46] Esteban MA, Wang T, Qin B, Yang J, Qin D, Cai J, et al. Vitamin C enhances the generation of mouse and human induced pluripotent stem cells. Cell Stem Cell. 2010 Jan 8; 6(1): 71-9.

[47] Yoshida Y, Takahashi K, Okita K, Ichisaka T, Yamanaka S. Hypoxia enhances the generation of induced pluripotent stem cells. Cell Stem Cell. 2009 Sep 4; 5(3): 237-41.

[48] Hong H, Takahashi K, Ichisaka T, Aoi T, Kanagawa O, Nakagawa M, et al. Suppression of induced pluripotent stem cell generation by the p53-p21 pathway. Nature. 2009 Aug 27; 460(7259): 1132-5.

[49] Kawamura T, Suzuki J, Wang YV, Menendez S, Morera LB, Raya A, et al. Linking the p53 tumour suppressor pathway to somatic cell reprogramming. Nature. 2009 Aug 27; 460(7259): 1140-4.

[50] Li H, Collado M, Villasante A, Strati K, Ortega S, Canamero M, et al. The Ink4/Arf locus is a barrier for iPS cell reprogramming. Nature. 2009 Aug 27; 460(7259): 1136-9.

[51] Marion RM, Strati K, Li H, Murga M, Blanco R, Ortega S, et al. A p53-mediated 
DNA damage response limits reprogramming to ensure iPS cell genomic integrity. Nature. 2009 Aug 27; 460(7259): 1149-53.

[52] Utikal J, Polo JM, Stadtfeld M, Maherali N, Kulalert W, Walsh RM, et al. Immortalization eliminates a roadblock during cellular reprogramming into iPS cells. Nature. 2009 Aug 27; 460(7259): 1145-8.

[53] Feng B, Jiang J, Kraus P, Ng JH, Heng JC, Chan YS, et al. Reprogramming of fibroblasts into induced pluripotent stem cells with orphan nuclear receptor Esrrb. Nat Cell Biol. 2009 Feb; 11(2): 197-203.

[54] Zhao Y, Yin X, Qin H, Zhu F, Liu H, Yang W, et al. Two supporting factors greatly improve the efficiency of human iPSC generation. Cell Stem Cell. 2008 Nov 6; 3(5): 475-9.

[55] Judson RL, Babiarz JE, Venere M, Blelloch R. Embryonic stem cell-specific microRNAs promote induced pluripotency. Nat Biotechnol. 2009 May; 27(5): 459-61.

[56] Miura K, Okada Y, Aoi T, Okada A, Takahashi K, Okita K, et al. Variation in the safety of induced pluripotent stem cell lines. Nat Biotechnol. 2009 Aug; 27(8): 743-5.

[57] Han J, Yuan P, Yang H, Zhang J, Soh BS, Li P, et al. Tbx3 improves the germ-line competency of induced pluripotent stem cells. Nature. 2010 Feb 25; 463(7284): 1096-100.

[58] Brons IG, Smithers LE, Trotter MW, Rugg-Gunn P, Sun B, Chuva de Sousa Lopes SM, et al. Derivation of pluripotent epiblast stem cells from mammalian embryos. Nature. 2007 Jul 12; 448(7150): 191-5.

[59] Tesar PJ, Chenoweth JG, Brook FA, Davies TJ, Evans EP, Mack DL, et al. New cell lines from mouse epiblast share defining features with human embryonic stem cells. Nature. 2007 Jul 12; 448(7150): 196-9.

[60] Ying QL, Wray J, Nichols J, Batlle-Morera L, Doble B, Woodgett J, et al. The ground state of embryonic stem cell self-renewal. Nature. 2008 May 22; 453(7194): 519-23.

[61] Silva SS, Rowntree RK, Mekhoubad S, Lee JT. X-chromosome inactivation and epigenetic fluidity in human embryonic stem cells. Proc Natl Acad Sci U S A. 2008 Mar 25; 105(12): 4820-5.

[62] Hanna J, Cheng AW, Saha K, Kim J, Lengner CJ, Soldner F, et al. Human embryonic stem cells with biological and epigenetic characteristics similar to those of mouse ESCs. Proc Natl Acad Sci U S A. 2010 May 18; 107(20): 9222-7.

[63] Lengner CJ, Gimelbrant AA, Erwin JA, Cheng AW, Guenther MG, Welstead GG, et al. Derivation of pre-X inactivation human embryonic stem cells under physiological oxygen concentrations. Cell. 2010 May 28; 141(5): 872-83.

[64] Daley GQ, Lensch MW, Jaenisch R, Meissner A, Plath K, Yamanaka S. Broader implications of defining standards for the pluripotency of iPSCs. Cell Stem Cell. 2009 Mar 6; 4(3): 200-1; author reply 2 . 
[65] Ellis J, Bruneau GB, Keller G, Lemischka IR, Nagy A, Rossant J, et al. Alternative Induced Pluripotent Stem Cell Characterization Criteria for In Vitro Applications. Cell Stem Cell. 2009; 4: 198-9.

[66] Yamanaka S. A fresh look at iPS cells. Cell. 2009 Apr 3; 137(1): 13-7.

[67] Doetschman TC, Eistetter H, Katz M, Schmidt W, Kemler R. The in vitro development of blastocyst-derived embryonic stem cell lines: formation of visceral yolk sac, blood islands and myocardium. J Embryol Exp Morphol. 1985 Jun; 87: 27-45.

[68] Schenke-Layland K, Rhodes KE, Angelis E, Butylkova Y, Heydarkhan-Hagvall S, Gekas C, et al. Reprogrammed mouse fibroblasts differentiate into cells of the cardiovascular and hematopoietic lineages. Stem Cells. 2008 Jun; 26(6): 1537-46.

[69] Narazaki G, Uosaki H, Teranishi M, Okita K, Kim B, Matsuoka S, et al. Directed and systematic differentiation of cardiovascular cells from mouse induced pluripotent stem cells. Circulation. 2008 Jul 29; 118(5): 498-506.

[70] Zhang J, Wilson GF, Soerens AG, Koonce CH, Yu J, Palecek SP, et al. Functional cardiomyocytes derived from human induced pluripotent stem cells. Circ Res. 2009 Feb 27; 104(4): e30-41.

[71] Kehat I, Kenyagin-Karsenti D, Snir M, Segev H, Amit M, Gepstein A, et al. Human embryonic stem cells can differentiate into myocytes with structural and functional properties of cardiomyocytes. J Clin Invest. 2001 Aug; 108(3): 407-14.

[72] Gepstein L. Derivation and potential applications of human embryonic stem cells. Circ Res. 2002 Nov 15; 91(10): 866-76.

[73] Xu C, Police S, Rao N, Carpenter MK. Characterization and enrichment of cardiomyocytes derived from human embryonic stem cells. Circ Res. 2002 Sep 20; 91(6): 501-8.

[74] Mummery C, Ward D, van den Brink CE, Bird SD, Doevendans PA, Opthof T, et al. Cardiomyocyte differentiation of mouse and human embryonic stem cells. J Anat. 2002 Mar; 200(Pt 3): 233-42.

[75] Mummery C, Ward-van Oostwaard D, Doevendans P, Spijker R, van den Brink S, Hassink R, et al. Differentiation of human embryonic stem cells to cardiomyocytes: role of coculture with visceral endoderm-like cells. Circulation. 2003 Jun 3; 107(21): 2733-40.

[76] Bu L, Jiang X, Martin-Puig S, Caron L, Zhu S, Shao Y, et al. Human ISL1 heart progenitors generate diverse multipotent cardiovascular cell lineages. Nature. $2009 \mathrm{Jul} 2$; 460(7251): 113-7.

[77] Kattman SJ, Huber TL, Keller GM. Multipotent flk-1+ cardiovascular progenitor cells give rise to the cardiomyocyte, endothelial, and vascular smooth muscle lineages. Dev Cell. 2006 Nov; 11(5): 723-32. 
[78] Moretti A, Caron L, Nakano A, Lam JT, Bernshausen A, Chen Y, et al. Multipotent embryonic isl1+ progenitor cells lead to cardiac, smooth muscle, and endothelial cell diversification. Cell. 2006 Dec 15; 127(6): 1151-65.

[79] Yamashita J, Itoh H, Hirashima M, Ogawa M, Nishikawa S, Yurugi T, et al. Flk1-positive cells derived from embryonic stem cells serve as vascular progenitors. Nature. 2000 Nov 2; 408(6808): 92-6.

[80] Yamashita JK, Takano M, Hiraoka-Kanie M, Shimazu C, Peishi Y, Yanagi K, et al. Prospective identification of cardiac progenitors by a novel single cell-based cardiomyocyte induction. FASEB J. 2005 Sep; 19(11): 1534-6.

[81] Takahashi T, Lord B, Schulze PC, Fryer RM, Sarang SS, Gullans SR, et al. Ascorbic acid enhances differentiation of embryonic stem cells into cardiac myocytes. Circulation. 2003 Apr 15; 107(14): 1912-6.

[82] Metzger JM, Lin WI, Johnston RA, Westfall MV, Samuelson LC. Myosin heavy chain expression in contracting myocytes isolated during embryonic stem cell cardiogenesis. Circ Res. 1995 May; 76(5): 710-9.

[83] Caspi O, Huber I, Kehat I, Habib M, Arbel G, Gepstein A, et al. Transplantation of human embryonic stem cell-derived cardiomyocytes improves myocardial performance in infarcted rat hearts. J Am Coll Cardiol. 2007 Nov 6; 50(19): 1884-93.

[84] van Laake LW, Passier R, Monshouwer-Kloots J, Verkleij AJ, Lips DJ, Freund C, et al. Human embryonic stem cell-derived cardiomyocytes survive and mature in the mouse heart and transiently improve function after myocardial infarction. Stem Cell Res. 2007 Oct; 1(1): 9-24.

[85] Nelson TJ, Martinez-Fernandez A, Yamada S, Perez-Terzic C, Ikeda Y, Terzic A. Repair of acute myocardial infarction by human stemness factors induced pluripotent stem cells. Circulation. 2009 Aug 4; 120(5): 408-16.

[86] Hattori F, Chen H, Yamashita H, Tohyama S, Satoh YS, Yuasa S, et al. Nongenetic method for purifying stem cell-derived cardiomyocytes. Nat Methods. 2009 Nov 29.

[87] Shimizu T, Sekine H, Yang J, Isoi Y, Yamato M, Kikuchi A, et al. Polysurgery of cell sheet grafts overcomes diffusion limits to produce thick, vascularized myocardial tissues. FASEB J. 2006 Apr; 20(6): 708-10.

[88] Seth S, Narang R, Bhargava B, Ray R, Mohanty S, Gulati G, et al. Percutaneous intracoronary cellular cardiomyoplasty for nonischemic cardiomyopathy: clinical and histopathological results: the first-in-man ABCD (Autologous Bone Marrow Cells in Dilated Cardiomyopathy) trial. J Am Coll Cardiol. 2006 Dec 5; 48(11): 2350-1.

[89] Messas E, Bel A, Morichetti MC, Carrion C, Handschumacher MD, Peyrard S, et al. Autologous myoblast transplantation for chronic ischemic mitral regurgitation. J Am Coll 
Cardiol. 2006 May 16; 47(10): 2086-93. 


\section{Figure legends}

Figure 1

Comparison of iPS cells generated by viral and non-viral methods. The iPS cells without genomic integration of exogenous sequences are generated by plasmid vectors, adenovirus, sendaivirus, and recombinant proteins. In iPS cells generated by piggyBac transposons, the piggyBac insertions can be removed by transposase.

Figure 2

A schematic representation of in vitro cardiomyocyte differentiation from ES/ iPS cells. 


\section{Figure 1}

\section{Somatic cells}

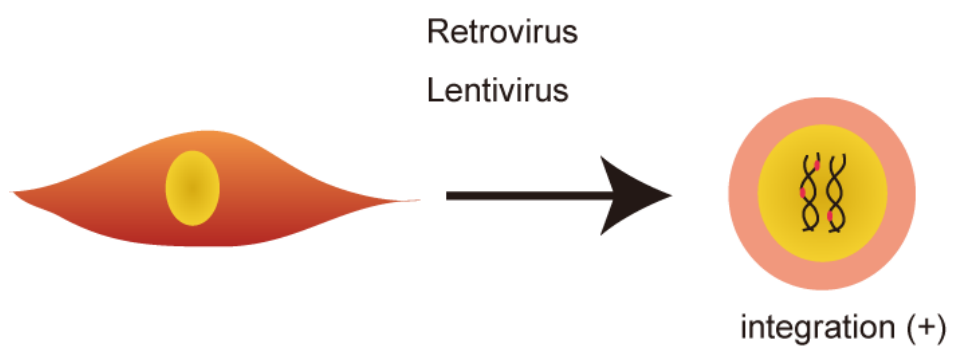

iPS cells
Plasmid vectors

Adenovirus

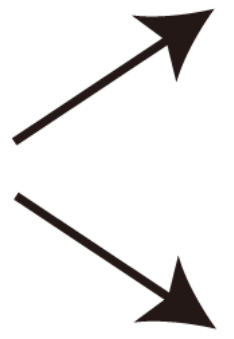

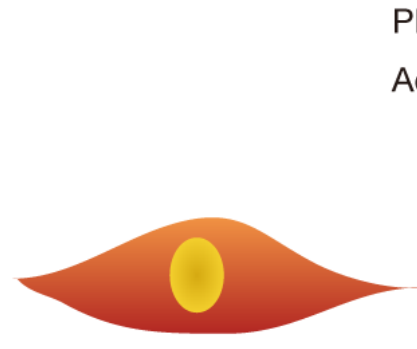

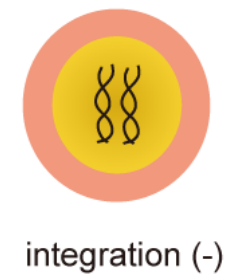

integration (-)

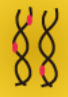

integration (+)

piggyBac transposons

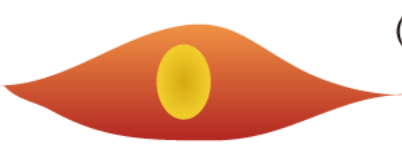

(+ transposase)
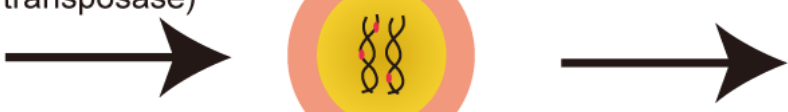

integration (+)

integration (-)

recombinant proteins

Sendaivirus

Synthetic mRNAs
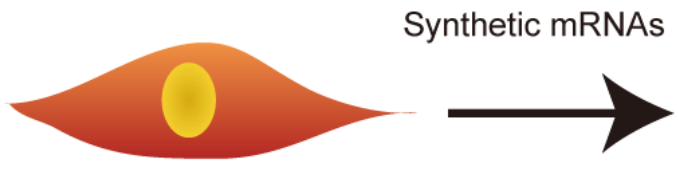

88

integration (-) 
Figure 2

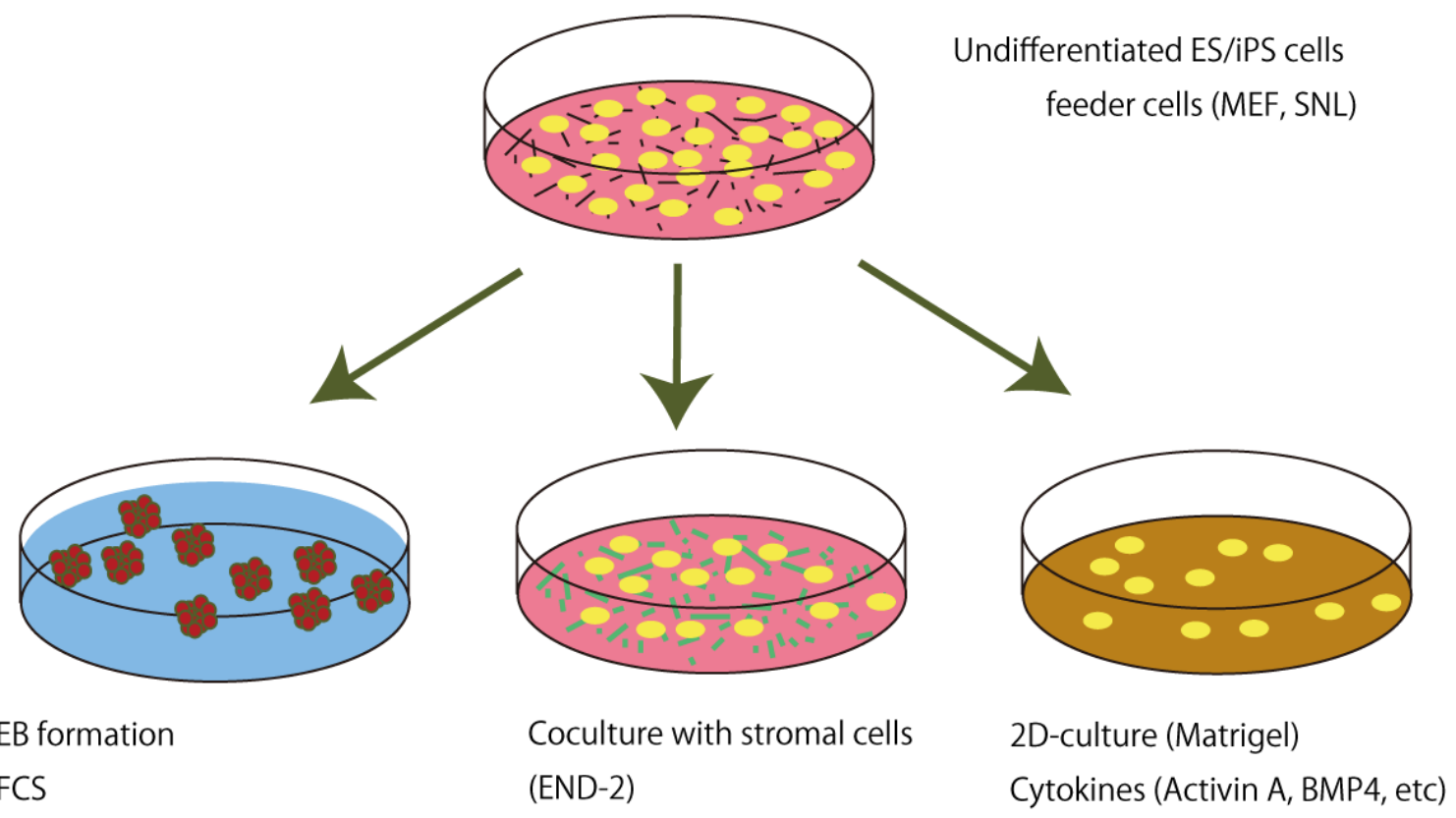

Cytokines (Activin A, BMP4, etc)

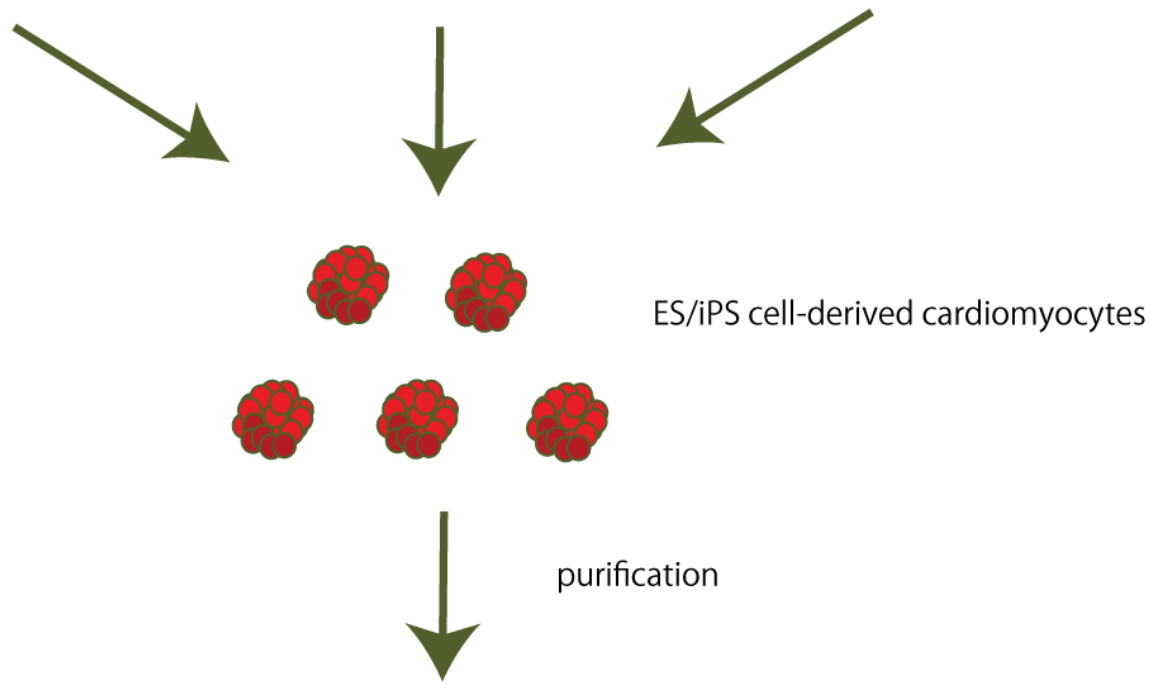

Cardiac regeneration

Pathogenetic study and drug screening 